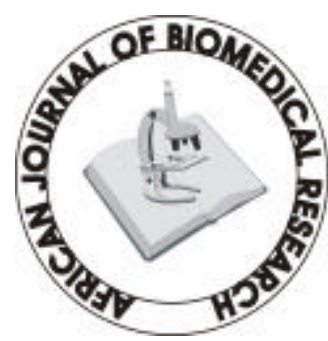

Full-text available at http://www.ajbrui.com \&

http://www.bioline.br/md

Received:

December, 2004

Accepted (Revised):

July, 2005

Published

January, 2006
Short communication

\section{Intestinal Helminth Parasites in School Children in Iragbiji, Boripe Local Government, Osun State, Nigeria.}

\author{
*Ijagbone, I. F. and T. F. Olagunju
}

Department of Veterinary Public Health and Preventive Medicine, University of Ibadan.

Ibadan, Nigeria

\section{ABSTRACT}

A survey of intestinal helminth parasites among school pupils was undertaken in five primary schools in Iragbiji Local Government of Osun State, South western Nigeria between April and June 2002. A total of five hundred and thirty-three faecal samples were randomly collected from pupils of both sexes whose ages ranged from six to seventeen years old. Using the direct and egg floatation techniques to process the faeces, 402 (72.0\%) of the samples were found positive for various intestinal helminths with Ascaris lumbricoide accounting for 46.0\%; Ancylostoma spp (Hookworm) 20.5\%; Strongyloides stercolalis 0.6\%; Fasciola hepatica $0.6 \%$, Trichuris trichuria 0.2\%; and mixed infections of Ascaris and Hookworm 1.9\%. Sex and age factors did not affect the pattern of infection since the parasites were found in both sexes and all age groups but with varying degrees. Infections were detected in all the schools investigated with one particular school recording infection rate of $100 \%$. The study shows that school pupils carry heavy intestinal parasite burden, which is an index of the prevailing unhygienic environment.

(Afr. J. Biomed. Res. 9: 63 - 66, 2006)

Keywords: Survey, Helminth, Parasites, School, Pupils.

*Author for Correspondence: (e-mail address): Tel: +234-0802-3342558

Abstracted by:

African Index Medicus (WHO), CAB Abstracts, Global Health Abstracts, Asian Science Index, Index Veterinarius 


\section{INTRODUCTION}

Intestinal helminth parasites are group of worms that use the body lumens of the gut as the normal locations for their adult forms. These parasites include among others the roundworms, hookworms and whipworms which cause high morbidity and mortality in both humans and domestic animals. In Sub-Saharan Africa, intestinal helminth infections are common and of major health concerns because factors that predispose man to the infections are abound in the sub-region. These factors include poor sanitation, poverty, malnutrition and ignorance. As a result, parasitic diseases in general have become indices of the low level of socio-economic status of the countries where the infections are prevalent.

In Nigeria, many intervention schemes which were attempted to control these infections did not yield much successes since people are still heavily infected, particularly children of school age (Nworgu, 1988). In this report, we present the result of a survey of intestinal helminth parasites among primary school children in Iragbiji town in Osun State of Nigeria. The ultimate aim was to find out the level of infections and possible impact on the pupils and then draw the attention of the Local Government Authority in the area to the need to adopt community health policies to alleviate the problem.

\section{MATERIALS AND METHODS}

\section{Study Area}

Iragbiji is the headquarters of Boripe Local Government located in Osun State of Nigeria. The town lies within the Tropical Rain Forest vegetation zone and the inhabitants are mostly peasant farmers. Over the years, the town had witnessed some tremendous developments in education and provisions of social and infrastructural facilities. There are eight primary schools located in the town, five of which served as the points of faecal collection from the school pupils.

\section{Faecal sample collection and examination}

Prior to the collection of faecal samples, permission was sought from the Chairman of the Boripe Local Government. This was granted and the respective schools were then duly informed of the study after which appointments for the collection were made. Before the collection, both the pupils and their teachers were appropriately educated about the aim and implication of the study. Five out of the eight schools in the Iragbiji were used for the investigation. Visits for the collection of samples were made in the mornings when the schools resumed for classes between April and June 2002. The pupils were usually assembled, lined up and specimen bottles were given to each of the pupils to drop their faeces which were carried out in the school toilets. The faeces were labelled with the pupils' names, who were also interviewed to obtain information on their health status. The samples were immediately taken to the laboratory for processing. The faeces were first examined for helminth eggs by direct wet preparations. This was done by emulsifying small quantities of the faeces in normal saline with Lugol's iodine solution and examined microscopically under cover slip. Further examination of the faeces was done by the Mac-Master egg-flotation method using saturated sodium chloride $(\mathrm{NaCl})$ solution. The number of eggs per gram of faeces was determined; followed by species identification using Baermann's method (Anon 1977).

\section{RESULTS}

Samples were collected from five primary schools in the Local Government Area as listed in Table 1. There were a total of 533 pupils examined, comprising of 263 males and 270 females: Out of the samples, four hundred and five $(72.0 \%)$ were infected with various helminthic parasites. Some individual pupils' haboured mixed infections. The faecal egg counts ranged from 600 to 3000 eggs per gram showing that the positive samples were heavily infected.

Out of the 263 males examined, 199 were infected (75.7\%) and of 270 females 203 (75.2\%) were also infected. The percentages of infection varied in the schools, ranging from 58 to 100 percent. Only one school, Saint Peter Primary School, had infection rate of 100\% showing that all the samples taken there were positive. This was followed by Christ Apostolic Church Primary School with $88.2 \%$. The ages of the pupils ranged between 6 and 17 years and infection was recorded in all the age groups. Table 2 shows the species of helminth parasites encountered. Ascaris lumbricoide formed the highest parasite detected, recording $245(47 \%)$ followed by Ancylostoma spp (hookworm) 109 (20 \%) Strongyloide stercoalis $3(0.56 \%)$. The least was Trichuris trichicura which was only $1(0.18 \%)$. Mixed infection of Ancyclostoma spp and Ascaris lumbricoide was recorded among 10 pupils (1.8 $\%)$. 
Table 1: The occurrence of Intestinal Parasites among School pupils in Iragbiji, Osun State: April - June 2002.

\begin{tabular}{|c|c|c|c|c|c|c|c|c|}
\hline \multirow[t]{2}{*}{ Schools } & \multirow{2}{*}{$\begin{array}{l}\text { No. of Pupils } \\
\text { in the } \\
\text { School }\end{array}$} & \multicolumn{2}{|l|}{ Males } & \multicolumn{2}{|l|}{ Females } & \multicolumn{2}{|l|}{ Total } & \multirow{2}{*}{$\begin{array}{l}\text { Total \% } \\
\text { Infection } \\
\text { - }\end{array}$} \\
\hline & & $\begin{array}{l}\text { No. } \\
\text { examine } \\
\text { d }\end{array}$ & $\begin{array}{l}\text { No. } \\
\text { +ve }\end{array}$ & $\begin{array}{l}\text { No. } \\
\text { examined }\end{array}$ & $\begin{array}{l}\text { No. } \\
\text { +ve }\end{array}$ & $\begin{array}{l}\text { No. } \\
\text { examined }\end{array}$ & No.+ve & \\
\hline $\begin{array}{l}\text { Saint Peter Primary School, } \\
\text { Oloti, Iragbiji }\end{array}$ & 721 & 49 & 49 & 60 & 60 & 109 & 109 & 100 \\
\hline $\begin{array}{l}\text { Christ Apostolic Church } \\
\text { Primary School 1, Popo, } \\
\text { Iragbiji }\end{array}$ & 476 & 52 & 46 & 50 & 44 & 102 & 90 & 88.2 \\
\hline $\begin{array}{l}\text { Local Authority School 1, } \\
\text { Popo, Iragbiji }\end{array}$ & 654 & 57 & 43 & 46 & 29 & 103 & 72 & 70.0 \\
\hline $\begin{array}{l}\text { Methodist Primary School, } \\
\text { Otapete, Iragbiji }\end{array}$ & 600 & 45 & 22 & 50 & 33 & 95 & 55 & 57.9 \\
\hline $\begin{array}{l}\text { Local Authority School II, } \\
\text { Easade, Iragbiji }\end{array}$ & 791 & 60 & 39 & 64 & 37 & 124 & 76 & 61.3 \\
\hline Total & 3242 & 263 & 199 & 270 & 203 & 533 & 402 & 72.0 \\
\hline
\end{tabular}

Table 2

Frequency of Species of Helminths among school pupils in Iragbiji, Osun State: April - June 2002

\begin{tabular}{lll}
\hline Species & No Examined & No Positive \\
\hline Ascaris lumbricoide & 533 & $245(46.0 \%)$ \\
\hline Hookworm & 533 & $109(20.5 \%)$ \\
\hline Strongyloide stercoralis & 533 & $3(0.56 \%)$ \\
\hline Fasciola hepatica & 533 & $3(0.56 \%)$ \\
\hline Trichuris trichuria & 533 & $1(0.18 \%)$ \\
\hline Mixed infections & 533 & $10(1.88 \%)$ \\
(Ascaris sp. and & & \\
Hookworm) & & \\
\hline
\end{tabular}

\section{DISCUSSION}

The result of the investigation demonstrates very clearly a high prevalence of intestinal helminth parasites among school pupils in Iragbiji, Boripe Local Government, Osun State, Nigeria. This may illustrate the general trend of the problem among school pupils throughout the country since the same environmental conditions abound everywhere. The most prevalent parasites in the area studied were Ascaris (roundworm) and Ancylostoma (hookworm) and in 10 cases, mixed infections of the two species were recorded.

The result of this study is consistent with earlier reports showing that intestinal helminthiasis caused by roundworms and hookworms is a common disease among rural and urban populations in Nigeria.

A review of some published figures illustrates the extent of the problem. For example, Okpala (1956) recorded an infection rate of 73 percent in over 4,700 Lagos children and adolescents. Onabamiro (1957) made a study of intestinal polyparasitism in 380 children at Abadina School in the University of Ibadan. Of these, 59 percent were infected with Ascaris, combined with hookworm and Trichuris. Giles (1964) reported infection rate of 70 percent in 600 villagers. It can be seen from these data, that the levels of prevalence have not changed over the years compared with the result of this report despite some improved environmental developments in the country. The increasing high incidence of helminthiasis among human communities in Nigeria is not surprising, considering that personal hygiene in these communities leaves much to be desired. Ascariasis which was found to be the highest infection in this investigation occurs mostly in children usually associated with insanitary conditions.

The humid climate provides favourable environmental conditions for the development of oval and larval stages of the parasites and their transmission to man. For instance, three different streams close to some of the primary schools were used as sources of drinking water and other domestic activities and also as refuse dumps. During some of the visits for sample collection, children were often seen around the streams taking water for drinking and other personal uses.

The delibilitating effects of intestinal parasitic infections on school children are many and include among others, malnutrition, kwashiorkor, emaciation, abdominal pains, and mental backwardness. Some of these features were observed physically among the children sampled and inspection of their schools reports. Some of them indeed 
complained of symptoms associated with parasitic diseases and absenteeism from school due to illnesses caused by helminthiasis. The high egg burdens recorded in the investigation was a reflection of the level of exposure of the children to helminthic parasites in the area. In order to control the condition, local health officers should visit the schools for routine deworming of the school children. Good personal hygiene must be encouraged at all levels of human activities and the Local Government Authorities must improve on the environmental disposal of human and other domestic wastes. Provision of potable water will also reduce the prevalence of parasitic infections.

\section{ACKNOWLEDGMENT}

We wish to express our sincere gratitude to the Officers of Boripe Local Government, Iragbiji for all the logistic support they provided that made the investigation possible.

\section{REFERENCES}

Anon, (1977): Manual of Veterinary Parasitological laboratory Techniques. Technical Bulletin No. 18. MAFF, London, 129 pp.

Giles, H. M. (1964): Akugo and environmental study of a Nigerian village community Ibadan. Ibadan University Press.

Nworgu, O. C. (1988) A school-based schistosomiasis and intestinal helminthiasis control programme in Nigeria: Acceptability to community members. Trop. Med. and Int. Health 3 (10): 842-9

Onabamiro, S. D. (1957): Intestinal poly parasitism among Nigeria school children. West African Journal Biol. Chem. 1 (3) 71-87.

Okpala, I. (1956): The incidence of Intestinal parasites among school children in Lagos, Nigeria. West Afr. Med. Journal 5, 107-170. 